This item was submitted to Loughborough's Research Repository by the author.

Items in Figshare are protected by copyright, with all rights reserved, unless otherwise indicated.

\title{
The relevance of Morris's utopia
}

\section{PLEASE CITE THE PUBLISHED VERSION}

http://dx.doi.org/10.1080/1084877042000311590

\section{PUBLISHER}

(c) Taylor and Francis

\section{PUBLISHER STATEMENT}

This work is made available according to the conditions of the Creative Commons Attribution-NonCommercialNoDerivatives 2.5 International (CC BY-NC-ND 2.5) licence. Full details of this licence are available at: https://creativecommons.org/licenses/by-nc-nd/2.5/

\section{LICENCE}

CC BY-NC-ND 2.5

\section{REPOSITORY RECORD}

Kinna, Ruth. 2019. “The Relevance of Morris's Utopia”. figshare. https://hdl.handle.net/2134/2097. 


\title{
는 Loughborough $\checkmark$ University
}

This article has been submitted to Loughborough University's Institutional Repository by the author.

\section{The Relevance of Morris's Utopia - Dr. Ruth Kinna}

\begin{abstract}
This paper considers the reputation of William Morris's News From Nowhere and its evaluation as a utopia. It argues that there is a discrepancy between scholarly estimations of the book's importance and its treatment as a utopia relevant to socialism. Whilst scholars have for many years almost unanimously praised News From Nowhere as Morris's crowning achievement, most have also attempted to argue that Morris did not intend his work to be used as a serious model for socialism. After reviewing some of the secondary literature and distinguishing between a variety of different interpretations of Morris's work, I suggest that the relevance of News From Nowhere might be assessed by the standards which Morris applied to Thomas More's Utopia. Considering Morris's work in this framework of utopianism, I argue that the relevance of Morris's utopia lies in what Norman Geras has called its ‘maximum’ vision.
\end{abstract}

Department of Politics, International Relations and European Studies, Loughborough University, Loughborough, LE11 3TU, UK. 
The Relevance of Morris's Utopia

Generations of Morris scholars have argued that William Morris's socialism has an enduring relevance. Yet there is also a marked tendency for scholars to distance themselves from the picture of communist society described in News From Nowhere. This treatment of Morris's work presents something of an anomaly: is it possible simultaneously to defend Morris's socialism, and disregard the content of his ideas? In this paper I attempt to explain the anomaly and to reconsider the relevance of Morris's socialism. I begin with a review of the critical assessments of News From Nowhere and argue that some of Morris's most stalwart champions have discussed News From Nowhere defensively, as if embarrassed by the romance of his utopia and Nowhere's medieval trappings. Either Morris's vision is said to be outmoded, or Morris is credited with writing an essentially modern utopia in which the details of the future are less important than the desire which that future is somehow supposed to stimulate. I suggest that the former is based on a misunderstanding of Morris's utopianism and that the latter is founded on an interpretation of utopianism that is too narrow. I suggest that Morris understood Nowhere as a literal idea of what the future could be and that romantic medievalism was central to his socialist vision. Morris believed that the work was educative and hoped that it might serve as an inspiration in the socialist struggle. But he did so precisely because it was an expression of his personal ideal. Treating News From Nowhere as a literal picture of socialism suggests that Morris's vision cannot be realised. But this conclusion does not condemn News From Nowhere to irrelevance. On the contrary, it is possible 
to argue that the strength of Morris's work rests on the totality and perfection of its vision. Moreover, by acknowledging the utopianism of News From Nowhere it is possible to delimit the range of conceivable futures - and ideological positions - to which Morris might otherwise be linked.

Morris may have exercised only a marginal influence on the Parliamentary Labour Party, but News From Nowhere has long been regarded with affection in all sections of the British socialist and labour movement. ${ }^{1}$ G.D.H. Cole and Barbara Castle both claimed that Morris's book played a central role in converting them to socialism. In The Future of Socialism Anthony Crosland celebrated Morris's aesthetic vision and his 'tender, respectful feeling for culture'. ${ }^{2}$ New Labour claim to have rediscovered Morris and paint him as a soul nearly lost to the blinkered ways of the past. ${ }^{3}$ On the centenary of Morris's death, Tony Blair claimed that News From Nowhere exercised a powerful influence on him when he was an undergraduate and he recently borrowed John Ball's idea that 'Fellowship is life, and lack of fellowship is death' to illustrate his thinking on informal community networks. ${ }^{4}$

Morris scholars have also enthusiastically celebrated Nowhere's imaginative power. Amongst pre-war writers, John Drinkwater argued that Morris's book was 'surely the loveliest dream that was ever recorded by a practical Utopian' ${ }^{5}$ Morris's utopia, Gerald Crow believed, was distinguished by its 'sheer loveliness'. 6 For Paul Bloomfield News From Nowhere was 'three things: Morris's masterpiece, and a masterpiece, and a sacred book' ${ }^{7}$ Post-war writers have been less effusive in their praise, but have continued to 
treat Nowhere with some reverence. A.L. Morton described it as the the crown and climax' of Morris's career. ${ }^{8}$ For E. P. Thompson it was 'a characteristic expression of Morris's genius' suffused with 'profound moral insight'. ${ }^{9}$ More recently, Fiona McCarthy has argued that it is Morris's 'most wonderfully disconcerting work': a 'visionary landscape ... both decorous and lavish, mysterious and homely, and extraordinary and deeply imagined image of urban possibility'. ${ }^{10}$

Admittedly, News From Nowhere has also drawn some fire. J.W. Mackail, one of Morris's earliest biographers, famously described it as a 'slightly constructed and essentially insular romance'. ${ }^{11}$ H.G. Wells admired the attractiveness of Morris's design, but judged his 'splendid anarchy' entirely impractical. $^{12}$ More pointedly, Raymond Williams argued that Nowhere was impractical and that it betrayed precisely those regressive influences which had characterised Morris's early poetry, holding back the development of his socialism. ${ }^{13}$ Yet none of these criticisms seem to have dented Nowhere's standing: even whilst arguing that Nowhere captures Morris's 'impulse towards simplification' Perry Anderson admits that Morris's work was a 'feat of moral imagination without equivalent in the work of Marx', that it was 'ignored without reason by Engels, and abandoned without sequel or echo in much later Marxism' ${ }^{14}$

In view of New's From Nowhere's standing, it is perhaps surprising that Morris's most enthusiastic defenders appear ambivalent about the arrangements the book describes. From the wealth of analyses that the book has attracted, it is possible to extract four main responses. The first, associated with G.D.H. Cole, treats News From Nowhere was a literal utopia 
and an accurate picture of the kind of society Morris wanted to see. The other three, for different reasons, reject this view.

Cole admitted that his interpretation of Nowhere suggested that Morris's socialism was hopelessly outmoded. Nowhere, 'presented an ideal to work for, or towards', but Cole 'was of course aware, even from the first' that it could not be regarded as 'a prophecy of what could come about in my own day or indeed, ever'. ${ }^{15}$ In Morris's defence, Cole found the relevance of News From Nowhere in the appealing picture of socialism it painted and in its political and socio-economic design. For Cole News From Nowhere remained an important book because it addressed the question of motivation in socialist struggle. It demonstrated that socialism should be regarded as something more than the outcome of historical development. Moreover, it was possible to extract certain principles of organisation from Morris's design and adapt them to suit the real world. For Cole these included the decentralisation of state power, the idea of co-operative labour and enjoyable work.

We can hardly avoid seeing that Morris's solution of the problem of production was unduly simple ... but let us beware of allowing the argument to carry us too far. Even if we admit ... there will be a shortage in the world of consumer goods to satisfy everybody's actual wants, it does not follow that the right course is to subordinate everything else to the quest for higher output, regardless of the conditions under which output has to be made. Morris was laying stress on a thoroughly valid point when he insisted that men could not be happy as long as they were condemned for most of their lives to kinds of toil that were irksome to them .... ${ }^{16}$

Those who have disagreed with Cole and rejected his central claim that Morris intended his book as a literal description of socialism have offered three alternative readings of Morris's work. One alternative sidesteps the 
issue of practicality altogether by concentrating instead on the idea that Morris wrote News From Nowhere in order to explore what he considered to be the key principles or values of socialism. Pre-war writers like John Drinkwater found these values in the imprint that Morris's character left on his utopia. News From Nowhere, he suggested, 'breathes a wonderful humanity. In this respect no other Utopia compares with it. It is not .... a book about how to make the world better. It is a picture of the world made better. It is a revelation of human personality'. ${ }^{17}$ Post-war writers have made a similar point. Philip Henderson, reacting to Cole's suggestion with some incredulity, argued that it was 'an insult to Morris's intelligence to suppose that he really believed in the possibility of such a society'. It was 'obvious enough that ... Morris was merely abolishing everything he disliked in the nineteenth century and replacing it by everything he nostalgically longed for'. ${ }^{18}$ Asa Briggs' estimation of Nowhere's worth was more measured: 'News From Nowhere ... sets out his Socialist criteria, particularly the equal relationships between people in a socialist society. It is in no sense of the word a literal picture of the future .... 19

The second alternative to Cole offers a stronger version of this first thesis and meets the criticism of impracticality with the suggestion that News From Nowhere was neither a literal nor a complete picture of Morris's socialism. The central thrust of this argument is that the overtly romantic and medieval tenor of Nowhere serves as an indication of Morris's poetic genius and not, as Cole would have it, a sign of his political simplicity. For A.L. Morton News From Nowhere was an allegory and its medievalism a literary device that perfectly suited Morris's medium. Of course, Nowhere was 
inspired by Morris's 'extraordinary skill in and love of handicrafts', but the near absence of technology in Nowhere did not demonstrate any general hostility on Morris's part to mechanisation or scientific development. ${ }^{20}$ Paul Thompson has advanced a similar view. News From Nowhere, he argues, 'was never intended to be a literal picture of a socialist utopia, but it was meant to convey a set of socialist values which were distinct from those of a mere rationalized state capitalism'. ${ }^{21}$ And for all its archaic traits - 'its timber houses and stone bridges, its handicrafts and gay costumes', News From Nowhere is really quite modern: there is 'electricity ... hidden behind the scenery'. ${ }^{22}$

The final alternative suggests that News From Nowhere was not a picture of socialism at all - literal, complete or otherwise. This interpretation does not dwell on Nowhere's utopian features and mounts a counter-offensive against those who would describe Nowhere as irrelevant. On this view, writers like Cole are guilty of misunderstanding Morris's purpose. E.P. Thompson was associated with this line of attack. In his 1976 Postscript to William Morris: Romantic to Revolutionary, he drew on the work of Miguel Abensour to distinguish between two utopian traditions: one which relied on 'juridico-political model building' and one which was rooted in imagination. ${ }^{23}$ News From Nowhere, he argued, belonged in the latter category: it was 'not Morris's intention ... to offer either doctrine or systematic description of the future society'. The 'function' of News From Nowhere was neither to offer 'propositions which can be validated in relation to text' nor to develop 'a strict societal model'. The 'proper and new-found space' of Morris's utopia was: 'the education of desire'. Here, Thompson's analysis dovetailed with Cole's, though his language was rather different. Drawing from Abensour, Thompson 
commented: 'This is not the same as "moral education" towards a given end: it is, rather to open a way to aspiration, to "teach desire to desire, to desire better, to desire more, and above all to desire in a different way"'. ${ }^{24}$

Thompson's interpretation of News From Nowhere has proved extremely persuasive. In recent years, it has been reinforced Krishan Kumar:

[Morris] came to see what other socialists had been reluctant to admit, that ... [socialism] required some vision, some comprehensive view of what it promised, if it were to win adherents. News from Nowhere is a dream of socialism; but Morris aspired to make it so alluring, so compelling, that others would wish to join in the task of realizing it, and so transform the dream into a collective vision that could remake the world. ${ }^{25}$

Work by Ruth Levitas and Fiona McCarthy also chimes in with Thompson. Utopia, Ruth Levitas argues, can either be a 'literal blueprint' or an 'education of desire': News From Nowhere falls into the latter category. In Fiona McCarthy's view Morris's book has an 'inner seriousness' which, contrary to appearances, 'releases the imagination by suggesting that another form of society is possible'. Critics who have pointed to the impossibility of Morris's arrangements have simply missed the point:

Many thousands of words have been spent on the interpreting of News From Nowhere, in intellectual contortions that would have kept Morris in guffaws. The laborious attacks on Nowhere's economics, its technology, it race relations, are absurd in a book that was never intended as a blueprint from which people could plan a working social system. ${ }^{26}$

Thompson's persuasive interpretation of News From Nowhere draws substantial contextual support first, from Morris's acceptance of Engels's critique of so-called 'utopian socialism' and second, from his desire to counter the vision of socialism portrayed in Edward Bellamy's hugely successful Looking Backward. Admittedly, scholars have disagreed on the first point, debating both Morris's relationship with the utopian socialists and the extent to 
which he intended to write a Marxist or scientific utopia. A.L. Morton advanced the boldest view, arguing that Morris used his book to expound ideas that Marx had developed in the Critique of the Gotha Programme. Paul Meier qualified Morton's standpoint. News From Nowhere was 'directly inspired by Marxist philosophy, taking into account the laws of historical development'. But Morris, Meier rightly pointed out, had also been influenced by the writings of the early utopian socialists - indeed, he drew 'unhesitatingly upon the ideology of that utopian socialism so frequently condemned or ridiculed by Marx and Engels' when he wrote his book. ${ }^{27}$ In Meier's view, Morris wrote News From Nowhere in order to make up for the omissions in Marx's and Engels' works: since neither had written about the future organization of communism, 'Morris felt that he legitimately had an open field and was entitled to bring into his predictions any borrowing which fitted the conception he desired to achieve'. ${ }^{28}$ In his Postscript, E.P Thomspon distanced himself from both Morton's and Meier's positions, revised his own early characterisation of News From Nowhere as a 'Scientific utopia' and openly questioned the usefulness of the distinction between utopian and scientific socialism. Nevetheless, Thompson continued to believe that Morris 'could (and did) take certain Marxist propositions as his point of departure'. And, like Morton and Meier, he explained Morris's intention to write News From Nowhere by his own opposition to the vulgar community-building schemes devised by Fourier, Owen and St. Simon. For all three, News From Nowhere was a socialist utopia, but Morris was not a utopian socialist.

The second point, that Morris wrote News From Nowhere as a response to Edward Bellamy, adds focus to this broad conclusion. Morris 


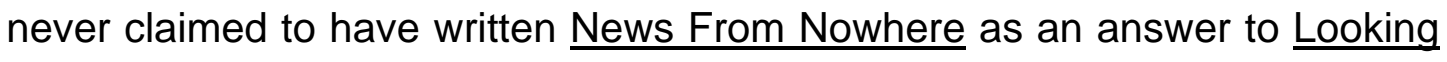
Backward but he certainly disliked the latter intensely, disturbed both by the ugliness of its mechanistic vision and the good impression that it was making in socialist and non-socialist circles alike. In June 1889, realising that Bellamy's book was being taken as a definitive description of socialist organisation, he wrote and long and damning review of it in Commonweal, dubbing its vision 'State Communism' and the 'very extreme of national centralization'. ${ }^{29}$ The timing and tone of this review, together with the obvious contrast that Nowhere strikes with Bellamy's Boston, have encouraged scholars to suggest that Morris wrote News From Nowhere as a reply to Looking Backward. E. P. Thompson went so far as to suggest that it was Morris's 'ever-present intention ... to contrast the simplicity of the life of "Nowhere" with the bureaucratic State Socialism (or "managerial revolution") of Bellamy's Looking Backward'. ${ }^{30}$ Fiona McCarthy similarly describes Looking Backward as the 'immediate spur to News from Nowhere' and compares the 'aridity of life in Bellamy's state Communist regime', the 'flat equality, the almost military regimentation of labour, [and] ... bureaucratic organisation' to the 'glitteringly fluid, poetic, open-ended News From Nowhere' ${ }^{31}$ From this perspective, Morris's genius was not just to have written, in Morton's words, the first modern utopia, but to have provided an image of socialism which - by implication at least - transcended the legacy of Soviet-style planning, even before it came into existence. And the lasting impression of the comparison with Bellamy is to reinforce the suggestion that the medieval flavour of Nowhere was merely an artistic device: Morris did not want us to live in a new medieval age, but deliberately romanticised his vision 
of the future in order to highlight the contrast between desirable socialism and the dull, mechanical socialism of Bellamy's Boston.

Morris's political writings add further weight to E.P. Thompson's interpretation. For example, the general point, that News From Nowhere was designed as an educative tract is sustained by the importance Morris attached to the role of ideas in history and, more particularly, to the idea of hope as an instrument of socialist change. As Cole put it: 'Morris was a revolutionary Socialist who believed in the power of ideas and ideals to transform the world'. ${ }^{32}$ In 'Communism', his famous 1893 lecture to the Fabians, Morris explained that socialist success turned on the imagination, as much as on courage or will. If the revolution were to succeed, the working class would have to develop 'a longing to bring about the complete change which will supplant civilization by communism'. ${ }^{33}$ From this point of view, News From Nowhere was a contribution to the 'education into Socialism of the working classe $^{, 34}$ - a contribution to his quest to turn socialism into a religion. In addition, as Thompson pointed out, Morris was deeply suspicious of old-style utopian socialism. Paul Meier usefully records Morris's reluctance to be drawn into 'prophecy' and his conviction that he was simply unable to abstract himself from his own historical conditions: he could not imagine the future even if wanted to do so. ${ }^{35}$ Morris was also familiar with Engels's Socialism Utopian and Scientific and broadly subscribed to his view that the utopians had mistakenly believed that socialism could be constructed from within the body of capitalism. Robert Owen's failings were typical. Like all utopians he 'ignored the antagonism of classes ... which in the long run must bring about the Socialism which he ... spent his whole life in attempting to realize' and he 
was unable to see that 'his experiments ... could never develope [sic] ... as long as the governors of Society forcibly uphold the so-called "rights to property"'. 36

But for all this, claims which suggest that Nowhere was not a literal picture of socialism seem deeply flawed. One problem is that they lead readers of Morris's work to believe that his description of Nowhere is immaterial. Indeed, E.P. Thompson stated as much. Though he believed that '[a]ssent may be better than dissent', he nevertheless suggested that the reader's approval of Nowhere was less important than the 'challenge to the imagination to become immersed in the same open exploration'. ${ }^{37}$ Why Morris bothered to give Nowhere a content and carefully locate it in a postrevolutionary future - rather than simply encourage us to 'dream' as he had done in The Earthly Paradise - remains a mystery.

A second problem with this view is that it appears to accept the validity of the critics' prejudices- and even reinforce them. G.D.H. Cole hinted at this problem in his 1956 lecture to the William Morris Society. Here, Cole suggested that E.P. Thompson had been 'legitimately eager to clear Morris of the charge so often made ... of having been merely a sentimental Socialist an artist sentimentally misled into an inappropriate application of his essentially aesthetic ideas .... 38 But Thompson's defence was too rigid and he leaned so far towards a dogmatic version of Marxism that his analysis of Morris's political thought was distorted. There were, moreover, important repercussions for his treatment of Morris's literature. Thompson's conviction that Morris had transformed late British Romanticism led him to consider many of the features that Morris imported into News from Nowhere from his 
early literature - his nostalgia, melancholy, simplicity - to be problematic. Whilst he recognised that Morris looked to his 'inheritance of dream and of fantasy' to frame his utopia he argued that Morris used this legacy only to highlight the difference between the real and the possible worlds. To acknowledge Morris's romanticism in any other way risked suggesting that News from Nowhere was a throw-back to the past. Implicitly Thompson and those who have followed his line of argument seem to accept that the romance of News From Nowhere is a potential defect and not a strength of Morris's work.

How then, should the relevance of Morris's work be understood? The answer to this question can be found in Morris's conception of the motivational power of ideas and ethical development. Morris developed his thoughts on this matter under the guidance of his friend, the social democratic theoretician, Ernest Belfort Bax. Though Morris did not follow all the twists and turns of Bax's complex philosophy, he did believe like Bax that there were two dynamics of historical change, one rooted in material life and the other in the realm of ideas. ${ }^{39}$ For Morris (though not for Bax), ethical development was marked by a striking continuity. Thus he traced the aspiration for socialism to the fourteenth century and credited the leaders of the Peasant's Revolt and, in the Tudor period, Sir Thomas More, with its initial elaboration. Morris did not however believe that ideas could by themselves bring about historical change. As he made clear in his account of the Peasants' Revolt, John Ball's dreams were destined to flounder because they lacked a material base in which to take root. His hopes would eventually be spoken of 'soberly, and as a thing soon to come about', but that would be in Morris's lifetime, not John Ball's. ${ }^{40}$ 
Yet ideas did not perish for want of a material base. The 'Fellowship of men', Morris assured John Ball, 'shall endure, however many tribulations it may have to wear through'. ${ }^{41}$ Looking back in history Morris detected the power of John Ball's dream in the most advanced currents of nineteenth century thought - for example, in the work of the utopians and the Communards and, naturally, in his own Socialist League.

Morris found perhaps the most important historical testament of the early ethic of socialism in Thomas More's Utopia and his treatment of More's book provides a significant insight into his conception of utopian thinking and its dynamic role in securing historical change. Morris was not the only socialist to show an interest in Utopia (as Morris himself noted, More's book, 'has in our days become a Socialist tract'). But in contrast to writers like Karl Kautsky, the German social democrat, who treated Utopia as a precursor of Socialism, linking it directly to the ideas of the utopian socialists, Morris treated Utopia as the product of a pre-modern age. Utopia, Morris argued, 'must be looked upon rather as the last of the old than the first of the new' ${ }^{42}$ Its significance for socialists was 'rather historic than propehetic'. ${ }^{43}$ The achievement of Utopia was to give expression to that hope for 'the spirit of association' and 'equality of condition' 44 that lay at the heart of fellowship and to do so by providing an outline of "'the best state of a publique weale"'. ${ }^{45}$

Morris treated these achievements in different ways. More's commitment to fellowship, which was inspired by his commitment to medieval Communism, had an enduring relevance and remained the 'essence of the struggle in which we are engaged'. ${ }^{46}$ In contrast, his 'idealised ancient society' or 'ideal vision' was a 'parable against the new spirit of his Age'. ${ }^{47}$ It 
was a protest, inspired by his love of the Renaissance, his hatred of 'the ugly brutality of the earliest period of Commercialism' and his philosophical and monkish asceticism. ${ }^{48}$ Morris was careful to add that his treatment of More's vision did not diminish the importance of More's work. He did not suggest, as modern writers were apt to do, that Utopia was 'nothing more serious than a charming literary exercise'. ${ }^{49}$ But he did suggest that More's utopia had a very different character from the utopias of the utopian socialists. More's purpose was not to 'regenerate Society by laying before it its short-comings, follies, and injustice' or to teach 'through precept and example certain schemes of reconstruction'. ${ }^{50}$ More did not set out to provide a 'refuge from mere destitution' (as Hammond believed Charles Fourier had wanted to do). ${ }^{51}$

Morris's analysis of More points to a distinction that is sometimes drawn between classical or medieval and modern utopias. Judith Shklar for example argued that classical are distinguished from modern utopias by their lack of concern with history. Classical utopias are 'an expression of the craftsman's desire for perfection and permanence'. ${ }^{52}$ They are models that invite 'contemplation and judgment' but which have no geographical or historical existence: they offer a vision 'not of the probable but of the "notimpossible"'. And they are characterised by an 'intellectual tension' which arises 'from the melancholy contrast between what might be and what will be'. ${ }^{53}$ Graus's discussion of modern and medieval utopias points to a similar contrast. Modern utopias are 'inevitably bound up with something future, something which is still to arise'. Utopias of the Middle Ages are more concerned with the notion of redemption, the 'restoration of a divine kingdom on earth at the end of time and in a heavenly paradise after death. The 
modern concept of an ideal society in the "historical" future is foreign to the Middle Ages' ${ }^{54}$ Morris did not express the distinction in these terms. Nevertheless, he was conscious that More could not be slotted into a modern tradition of theorising. Indeed, his treatment of More implies a tri-partite analysis of utopia which distinguishes between a pre-modern, utopian socialist and modern utopian tradition, in contrast to the bi-partite system favoured by most of Morris's defenders.

If Morris read More's work as a pre-modern utopia, News From Nowhere might be said to straddle this and the modern tradition. Certainly, Morris followed More in a number of ways. First, as G.D.H. Cole noted, he offered a personal vision. Utopia had been tempered by More's 'own experiences of his time and people' and his 'curious fancies'. Nowhere, too, was - as Morris termed it - an 'egotistical work' which captured his particular preoccupations, hopes and desires. ${ }^{55}$ Utopia was 'harmonised by a sensitive clearness and delicate beauty of style' which made it a 'living work of art'. Similarly, News From Nowhere was written with the mystery and strangeness of a romance. Its style sets the work apart from essays like 'How shall we live then?' or 'The Society of the Future', in which Morris again detailed his 'personal view of the Promised Land of Socialism'. ${ }^{56}$ Morris's book, as John Bruce Glasier suggested, was a socialist 'jeu d'esprit, a fancy picture, or idyll'. ${ }^{57}$ Like More, Morris wrote News From Nowhere with a sense of foreboding. Utopias, he argued, arose at times of 'conscious change' when we feel ... ourselves to be living between the old and the new ... expecting something to happen'. ${ }^{58}$ In Morris's judgement, More had been aware that he lived in a 'period of transition from Medieval to Commercial Society' and, 
acutely attuned to 'all its brutalities' he had imagined the society that he wished would develop from the chaos and confusion. Three hundred and seventy-five years later, Morris believed that he was witnessing the next stage of historical development: the shift from capitalism, or commerce, to socialism. Anticipating that this transition would first establish a society roughly in the form that Bellamy described, he wrote News From Nowhere to describe what he considered 'likely to take place later on, when Socialism shall have taken deeper roots'. Finally, just as More had painted 'a picture (his own indeed, not ours) of the real New Birth which many men before him had desired' Morris also believed that his utopia met a widespread longing for a better way of life. ${ }^{59}$ News From Nowhere was a personal utopia, yet Morris argued that he was not 'so utterly different' from other people and he was not surprised to find that 'a good many people' found his 'own aspirations pleasant'. 60 Like Utopia, News From Nowhere tapped into the popular psyche and in this sense it provided a literal picture of the way society should be.

As a modern utopian, Morris diverged from More in three important respects. First, unlike More, Morris had a sense of historical progress: he dedicated two substantial chapters to the discussion of the process of revolution in 'How the Change Came'. Admittedly, Morris did not expect to see socialism established in his lifetime. Indeed, one of the many revisions Morris made between the serialization of the story in Commonweal and its publication as the novel was to back-date the year of the revolution. And the tenor of News from Nowhere is one of overwhelming melancholy. In Nowhere Guest believes that he has found heaven on earth, but he can only see this 'new life from the outside' with all the 'prejudices, the anxieties, the 
distrust' of his present. In the end, he cannot stay: he must return to 'the unhappiness' of Nowhere's past. ${ }^{61}$ Nonetheless, Nowhere is set in real time. Moreover, whereas More suggests at the end of the book that he wishes but does not 'expect to see' any aspects of Utopia incorporated into his own society, the narrator of News From Nowhere raises the possibility that Nowhere is a 'vision rather than a dream'. ${ }^{62}$

Morris also departed from More by using his commentary to attack existing society. Unlike More, he did not offer a critical commentary on his utopia. In More's work, utopia is discussed by two main characters - More and Hythloday - who disagree in their approach to practical affairs. In contrast, Morris's dreamer, the silent man 'up at the League', who becomes Guest in the story, and the comrade who relates his dream share identical 'feeings and desires'. ${ }^{63}$ Utopia's characters reflect More's indecision about the best state of the commonwealth and his unwillingness to pass final judgement on such an issue. ${ }^{64}$ Morris's characters, on the other hand, suggest a firm commitment to Nowhere's arrangements. Indeed, the relationship between Guest and Hammond, the detached but enthusiastic guide the Nowhere's way of life, further emphasises this commonality of view. For rather than challenging any of the details Hammond gives about Nowhere's arrangements or his criticisms of the Victorian past, Guest imagines himself in Hammond's shoes, enjoying the new life that he describes.

Morris again departed from More by giving his discussion of utopia an ideological context. Morris opened his book with a description of a discussion between four anarchists and two others - the dreamer and his friend - about 
what would happen 'on the Morrow of the Revolution'. He was perhaps inspired here by Bax who, in an essay entitled 'The Morrow of the Revolution' encouraged socialists to give an indication of their future intentions and, more pragmatically, to thrash out any disagreements they might have 'before rather than after they are called upon to act'. ${ }^{65}$ In any event, Nowhere is presented as an alternative to anarchy. Though Morris did not pursue a strongly ideological debate in his story he was sufficiently moved to press in the main text those arguments about individualism and the necessity for a 'public conscience' that he had had with the anarchists just prior to his resignation from the League. ${ }^{66}$ Morris was clearly deeply concerned with the problem of anarchist individualism, as he saw it; and his decision to raise the issue at all in News From Nowhere reflected the importance he attached to the political details of this utopian design.

What does this treatment of Morris's utopianism suggest about the relevance of News From Nowhere as a model for socialism? It seems perhaps to confirm G.D.H. Cole's assessment. As a literal description of socialism, Morris's ideal looks impossible and outmoded. As Cole asserted, Morris predicated Nowhere on the assumption that scarcity would be abolished and that the abolition of capitalist exploitation would by itself put an end to poverty. ${ }^{67}$ Morris's people are content to live simple lives and to restrict their wants. They are all equally absorbed by their labour. It is a world of 'static perfection'. The weather is always fine, the colours ever-bright and the people 'healthy, good-looking, and good-humoured'. ${ }^{68}$ Morris's vision was 'idyllic', but life could never be 'quite so easy going, or man or nature quite so kind'. 69 
However, this reading of News From Nowhere, as a hybrid of premodern and modern utopias, invites a rather different response to the one presented by Cole. If Morris designed Nowhere at least in part as a classical utopia, it seems unreasonable to try to divorce his ethical view from his politics, as Cole and, with a different purpose, those who follow E.P. Thompson have attempted to do. Morris's reading of More is instructive here. To Morris's eyes, More's political proposals looked outdated: 'he speaks words that would not be out of place in the mouth of an eighteenth-century Jacobin; and at first sight this seems rather to show sympathy with what is now mere Whigism than with Communism'. ${ }^{70}$ But Morris did not try to isolate More's ideas about the monarchy, for example, from those that he believed had some value to this own cause. Nor did he attempt to disregard them as if they were of no importance. More's proposals were not to be applied or to be rejected. On the contrary, whilst Morris argued that More's ideas could be judged only by the standards of their time he defended the integrity of More's utopia as a sixteenth-century expression of an ethical system. News From Nowhere surely deserves to be treated with the same respect.

Nowhere describes what Norman Geras has called a 'maximum utopia': a 'condition of uncoerced social peace and of free and ample individual self-realization'. ${ }^{71}$ Maximum notions of utopia, Geras argues, have an 'indispensable place' in socialist thought for they nourish 'visions of a radically different human realm'. They suggest that the 'extraordinary is already within the ordinary' and raise the possibility that the ordinary might be limitlessly extended. ${ }^{72}$ Indeed, it seems odd to want to defend the moral, educative force of Morris's utopia whilst effectively stripping it of its content. 
And there is a price to pay for cherry-picking Morris's apparently attractive or useful ideas and harnessing them to modern campaigns. That price is Morris's standing as a visionary and revolutionary. Of course, G.D.H. Cole was deeply immersed in socialist history and his profound sympathy for Morris's political thought shone through his treatment of News From Nowhere. Yet others, who have found inspiration in Morris's utopianism, have only diminished its value: there is something faintly ridiculous in harnessing John Ball to the promotion of a public policy agenda. 
Bibliography

Anderson, Perry. Arguments within English Marxism. London: NLB and Verso Edition, 1980.

Bax, Ernest Belfort. The Ethics of Socialism. London: Swann Sonnenschein \& Co., n.d.

Blair, Tony. "My Vision For Britain." The Observer Comment: The Crime and Justice Debate, no. November 10 (2002).

Bloomfield, Paul. William Morris. Barker, 1934.

Cole, G.D.H. William Morris as a Socialist. London: William Morris Society, 1960.

Crow, G.H., and Ed by C.G. Holme. William Morris, designer. Studio, 1934.

Drinkwater, John. William Morris : a critical study. London: Martin Secker, 1912.

Geras, N. "Minimum Utopia: Ten Theses." In Socialist Register 2000 Necessary and Unnecessary Utopias. Suffolk: Merlin Press, 1999, 41.

Glasier, John Bruce. William Morris and the Early Days of the Socialist Movement. Bristol: Thoemmes Press, 1994.

Graus, F. "Social Utopias in the Middle Ages." Past and Present 38, no. December (1967): 3-19.

Hain, Peter. "The Past in New Labour's Future." The Observer Comment, no. October 27 (2002).

Henderson, Philip. William Morris: his life, work and friends. Harmondsworth: Penguin, 1973.

Kinna, Ruth. William Morris : the art of socialism. Cardiff: University of Wales Press, 2000.

Mackail, J.W. The Life of William Morris. London: Longmans, Green and Co., 1912.

McCarthy, F. William Morris A Life For Our Time. London: Faber and Faber, 1994.

Meier, Paul. William Morris : the Marxist dreamer. Hassocks: Harvester Press etc., 1978.

More, Thomas. Utopia. Edited by George M. Logan, Robert M. Adams and 
Clarence H. Miller. Cambridge: Cambridge University Press, 1995.

Morris, May,Daughter of William Morris. William Morris: artist, writer, socialist. Oxford: Basil Blackwell, 1936.

Morris, William. News From Nowhere. Edited by Krishan Kumar. Cambridge: Cambridge University Press, 1995.

Morris, William. News From Nowhere and Selected Writings and Designs. Edited by Asa Briggs. Harmondsworth: Penguin, 1980.

Morris, William. Selected Writings. Edited by G.D.H. Cole. London: Nonesuch Press, 1974.

Morris, William. Political writings : contributions to Justice and Commonweal, 1883-1890. Edited by Nicholas Salmon. Bristol: Thoemmes, 1994.

Morris, William, and May Morris. The collected works of William Morris. London, Routledge/Thoemmes Press:1992. vol. IX.

Morris, William, and May Morris. The collected works of William Morris. London, Routledge/Thoemmes Press:1992. vol. XXIII.

Morton, A.L. The English Utopia. London: Lawrence and Wishart, 1978.

Platt, Steve, and Julia Gallagher. "From Bevan to the Bible." New Statesman and Society no. 30 September (1994): 22-4.

Shklar, Judith. "The Political Theory of Utopia: From Melancholy to Nostalgia." Daedalus 94, no. 2 (1965): 367-82.

Thompson, E.P. William Morris : romantic to revolutionary. New York: Pantheon Books, 1976.

Thompson, Paul. The Work of William Morris. 3rd ed. Oxford: Clarendon, 1991.

Wells, H.G. A Modern Utopia. Lincoln and London: University of Nebraska Press, 1967.

Williams, R. Culture and Society 1780-1950. Harmondsworth: Penguin, 1971.

\footnotetext{
${ }^{1}$ In the 1962 New Society survey of Labour MPs, 13\% suggested that Morris had exercised an important influence on their beliefs. Morris did not feature in similar surveys conducted in 1975 or 1994. Steve Platt and Julia Gallagher, "From Bevan to the Bible," New Statesman and Society, no. 30 September (1994): 22.

${ }_{2}^{2}$ C.A.R. Crosland, The Future of Socialism, (London: Jonathan Cape, 1964) 361.

3 Peter Hain, "The Past in New Labour's Future," The Observer Comment, no. October 27 (2002):

${ }^{4}$ Tony Blair, "My Vision For Britain," The Observer Comment: The Crime and Justice Debate, no. November 10 (2002):
} 
${ }^{5}$ John Drinkwater, William Morris : a critical study, (London: Martin Secker, 1912) 17.

${ }^{6}$ G.H. Crow (ed), William Morris, designer, (The Studio, 1934) 93.

7 Paul Bloomfield, William Morris, (Arthur Barker, 1934) 282.

${ }^{8}$ A.L. Morton, The English Utopia, (London: Lawrence and Wishart, 1978) 208.

9 E.P. Thompson, William Morris : romantic to revolutionary, (New York: Pantheon Books, 1976),692;717.

${ }^{10}$ F. McCarthy, William Morris A Life For Our Time, (London: Faber and Faber, 1994) 583;587.

11 J.W. Mackail, The Life of William Morris, vol. 2, (London: Longmans, Green and Co., 1912), 256.

${ }_{12}$ H.G. Wells, A Modern Utopia, (Lincoln and London: University of Nebraska Press, 1967),

7.

${ }_{13}$ R. Williams, Culture and Society 1780-1950, (Harmondsworth: Penguin, 1971), 159.

14 Perry Anderson, Arguments within English Marxism, (London: NLB and Verso Edition, 1980), 160;167.

15 G.D.H. Cole, William Morris as a Socialist (London: William Morris Society, 1960), 2.

16 ibid.

17 Drinkwater, William Morris : a critical study, 289.

18 Philip Henderson, William Morris: his life, work and friends, (Harmondsworth: Penguin, 1973), 386-7.

19 William Morris, News From Nowhere and Selected Writings and Designs, ed. Asa Briggs (Harmondsworth: Penguin, 1980), 17-18.

20 Morton, "The English Utopia," 216.

${ }^{21}$ Paul Thompson, The work of William Morris, $3^{\text {rd }}$ ed. (Oxford: Clarendon, 1991), 178.

22 ibid. 260.

23 Thompson, "William Morris : romantic to revolutionary," 789-90.

24 ibid. 791.

${ }^{25}$ William Morris, News From Nowhere, ed. Krishan Kumar (Cambridge: Cambridge

University Press, 1995), xxiii.

${ }_{26}$ McCarthy, "William Morris A Life For Our Time,"

27 Paul Meier, William Morris : the Marxist dreamer, vol. 2, (Hassocks: Harvester Press etc., 1978), 576-7).

${ }^{28}$ ibid. vol. 1, 165.

${ }^{29}$ William Morris, in Nicholas Salmon (ed.), Political writings : contributions to Justice and Commonweal, 1883-1890, (Bristol: Thoemmes, 1994), 422.

30 Thompson, William Morris : romantic to revolutionary, 692.

${ }_{31}$ McCarthy, William Morris A Life For Our Time, 584.

32 Cole, William Morris as a Socialist, 14.

33 William Morris, The Collected Works of William Morris, vol. XXIII, (London: Routledge/Thoemmes Press, 1992) 270.

${ }^{34}$ Ibid. 268.

${ }^{35}$ Meier, William Morris : the Marxist dreamer, vol. 2, 574.

${ }_{36}$ Morris, in Salmon (ed.), Political writings : contributions to Justice and Commonweal, 1883$1890,565$.

37 Thompson, William Morris : romantic to revolutionary, 790.

${ }^{38}$ Cole, William Morris as a Socialist, 16.

39 Ruth Kinna, William Morris : the art of socialism, (Cardiff: University of Wales Press, 2000), 97-99.

40 William Morris, The collected works of William Morris, vol. XVI, (London,

${ }^{41}$ Ibid. 284 Routledge/Thoemmes Press:, 1992), 285.

${ }^{42}$ William Morris in May Morris (ed.), William Morris: artist, writer, socialist. (Oxford: Basil

Blackwell, 1936), vol. 2, 289.

43 ibid.

44 ibid.290-1.

45 ibid. 289.

46 ibid. 291.

47 ibid.290. 
48 ibid. 291.

49 ibid. 289.

50 William Morris \& E.B. Bax, Socialism From the Root Up, in Salmon (ed.), Political writings : contributions to Justice and Commonweal, 1883-1890, 563.

${ }^{51}$ Morris, The collected works of William Morris, vol. IX, 56.

52 Judith Shklar, "The Political Theory of Utopia: From Melancholy to Nostalgia," Daedalus

94, no. 2 (1965), 371.

53 ibid. 370-1.

${ }^{54}$ F. Graus, "Social Utopias in the Middle Ages," Past and Present 38, no. December (1967): 8-9

${ }^{55}$ William Morris, “How Shall We Live Then?", ed. Paul Meier, "An Unpublished Lecture of William Morris", International Review of Social History, XVI, (1971), 223.

${ }^{56}$ For a discussion see Kinna "William Morris: The Art of Socialism", 198-202.

57 John Bruce Glasier, William Morris and the Early Days of the Socialist Movement, (Bristol: Thoemmes Press, 1994) 151.

${ }^{58}$ Morris, The collected works of William Morris, XXIII, 59;122.

59 Morris in May Morris ed. William Morris: artist, writer, socialist, vol. 2, 290;292.

${ }^{60}$ Morris, "How Shall We Live Then?", 223.

61 Morris The collected works of William Morris, XVI, 210.

62 On the relationship between Morris and More on this point see David Leopold's introduction to News From Nowhere, (Oxford: Oxford University Press, 2003)

${ }^{63}$ Morris, The collected works of William Morris, XVI, 5.

64 Thomas More, Utopia, ed. George M. Logan, Robert M. Adams and Clarence H. Miller (Cambridge: Cambridge University Press, 1995) xxv.

${ }^{65}$ Ernest Belfort Bax, The Ethics of Socialism, (London: Swann Sonnenschein \& Co., n.d.) 84.

${ }^{66}$ For a discussion see Kinna, "William Morris: The Art of Socialism", 137-46.

67 Cole, William Morris as a Socialist, 5.

68 William Morris, Selected Writings, ed. G.D.H. Cole (London: Nonesuch Press, 1974), 22.

69 ibid.

${ }^{70}$ Morris in May Morris (ed), William Morris: artist, writer, socialist, vol. 2, 291.

71 N. Geras, "Minimum Utopia: Ten Theses," in Socialist Register 2000 Necessary and Unnecessary Utopias (Suffolk: Merlin Press, 1999), 43.

72 ibid. 